\title{
Soil salinity related to physical soil characteristics and irrigation management in four Mediterranean irrigation districts
}

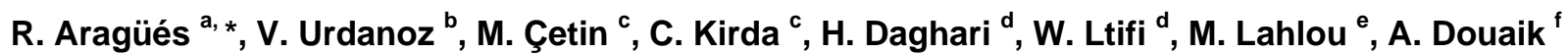

${ }^{\text {a }}$ Soil and Irrigation Department (EEAD-CSIC Associated Unit), Agrifood Research and Technology Center of Aragón (CITA), Aragón Government, Avenida de Montañana 930, 50059 Zaragoza, Spain

${ }^{\mathrm{b}}$ Trabajos Catastrales S.A., calle Cabárceno 6, 31621 Sarriguren, Navarra, Spain

${ }^{\mathrm{c} C ̧ u k u r o v a}$ University, Faculty of Agriculture, 01330 Balcali, Adana, Turkey

d University of $7^{\text {th }}$ November at Carthage, Water Resources Management and Conservation Research Unit, National Agronomic Institute of Tunisia (INAT), 43 avenue Charles Nicolle, Cité Mahragène, Tunis 1002, Tunisia

${ }^{\mathrm{e}}$ Department of Statistics and Computer Science, Institute of Agronomy and Veterinary Hassan II, P.O. Box 6202, Rabat-Instituts, 10101 Rabat, Morocco

${ }^{f}$ Research Unit on Environment and Conservation of Natural Resources, Regional Center of Agricultural Research of Rabat, National Institute of Agricultural Research, BP 415 Avenue de la Victoire, 100000 Rabat, Morocco

*Corresponding author. Tel.: +34 976716 357; fax: + 34976716 335. E-mail address: raragues@aragon.es 


\section{Abstract}

Irrigated agriculture is threatened by soil salinity in numerous arid and semiarid areas of the Mediterranean basin. The objective of this work was to quantify soil salinity through electromagnetic induction (EMI) techniques and relate it to the physical characteristics and irrigation management of four Mediterranean irrigation districts located in Morocco, Spain, Tunisia and Turkey. The volume and salinity of the main water inputs (irrigation and precipitation) and outputs (crop evapotranspiration and drainage) were measured or estimated in each district. Soil salinity $\left(E_{\mathrm{e}}\right)$ maps were obtained through electromagnetic induction surveys $\left(\mathrm{EC}_{\mathrm{a}}\right.$ readings) and district-specific $\mathrm{EC}_{\mathrm{a}}-\mathrm{EC}_{\mathrm{e}}$ calibrations. Gravimetric soil water content $(\mathrm{WC})$ and soil saturation percentage (SP) were also measured in the soil calibration samples. The $\mathrm{EC}_{\mathrm{a}}-\mathrm{EC}_{\mathrm{e}}$ calibration equations were highly significant $(P<0.001)$ in all districts. $E C_{a}$ was not significantly correlated $(P>0.1)$ with WC, and was only significantly correlated $(P<0.1)$ with soil texture (estimated by SP) in Spain. Hence, ECa mainly depended upon $\mathrm{EC}_{\mathrm{e}}$, so that the maps developed could be used effectively to assess soil salinity and its spatial variability. The surface-weighted average $\mathrm{EC}_{\mathrm{e}}$ values were low to moderate, and ranked the districts in the order: Tunisia $\left(3.4 \mathrm{dS} \mathrm{m}^{-1}\right)>\operatorname{Morocco}\left(2.2 \mathrm{dS} \mathrm{m}^{-1}\right)>$ Spain $\left(1.4 \mathrm{dS} \mathrm{m}^{-1}\right)>$ Turkey $\left(0.45 \mathrm{dS} \mathrm{m}^{-}\right.$ $\left.{ }^{1}\right)$. Soil salinity was mainly affected by irrigation water salinity and irrigation efficiency. Drainage water salinity at the exit of each district was mostly affected by soil salinity and irrigation efficiency, with values very high in Tunisia $\left(9.0 \mathrm{dS} \mathrm{m}^{-1}\right)$, high in Spain $\left(4.6 \mathrm{dS} \mathrm{m}^{-1}\right)$, moderate in Morocco (estimated at $2.6 \mathrm{dS} \mathrm{m}^{-1}$ ), and low in Turkey $\left(1.4 \mathrm{dS} \mathrm{m}^{-1}\right)$. Salt loads in drainage waters, calculated from their salinity $\left(E C_{d w}\right)$ and volume $(Q)$, were highest in Tunisia (very high $\mathrm{Q}$ and very high $\mathrm{EC}_{\mathrm{dw}}$ ), intermediate in Turkey (extremely high $\mathrm{Q}$ and low $\mathrm{EC}_{\mathrm{dw}}$ ) and lowest in Spain (very low $\mathrm{Q}$ and high $\mathrm{EC}_{\mathrm{dw}}$ ) (there were no $\mathrm{Q}$ data for Morocco). Reduction of these high drainage volumes through sound irrigation management would be the most efficient way to control the offsite salt-pollution caused by these Mediterranean irrigation districts.

\section{Keywords:}

Electromagnetic induction (EMI), Mediterranean agriculture, irrigation management, irrigation water salinity, drainage water salinity, salt load 


\section{Introduction}

Irrigation is vital for agricultural production in arid and semi-arid areas with scarce or irregular precipitation, but its misuse may cause negative effects on the quality of soils (Lal and Stewart, 1990) and waters (Aragüés and Tanji, 2003). A serious threat to sustainable irrigated agricultural production is secondary salinization since estimates indicate that, globally, $20 \%$ of irrigated land suffers salinization induced by the build-up of salts caused by irrigation (Wood et al., 2000).

Salt accumulation in Mediterranean soils is a natural process favored by the ecological conditions of the region, governed first and foremost by the water balance of the area (Zalidis et al., 2002). Human activities, particularly irrigation in relatively flat arable lands, may profoundly modify this water balance and may cause salt accumulation under limited drainage conditions, so accelerating land degradation in semiarid Mediterranean environments. According to FAO estimates gathered by the terrastat database, the saltaffected areas in the Mediterranean basin amount to 27.3 million ha, with about 7.3 million ha in the four countries studied (Morocco, Spain, Tunisia and Turkey).

A proper knowledge of the effects of irrigation on the spatial and temporal variability of salt-affected soils is essential to assess the magnitude and trends of this soil quality problem and its effects on water quality. In the Mediterranean basin, soil and climate variability, combined with small-sized farms, results in a wide range of different soil and water management practices. Since geographical information systems (GIS) facilitate the processing of large data collections (Çetin and Diker, 2003), the real challenge in such situations is the appropriate and accurate acquisition of spatial and temporal salinity data. Because such data collection through conventional soil sampling and laboratory analysis is not affordable for large areas, assessment of the spatial and temporal variability of soil salinity in complex Mediterranean landscapes requires the development of alternative, dependable and low-cost methodologies aimed at providing information about the status of soil salinity as affected by different soil, crop and irrigation management practices.

Electromagnetic induction (EMI) instruments have been used for three decades to perform bulk apparent soil electrical conductivity $\left(E_{a}\right)$ measurements (Rhoades et al., 1999). These cost-effective, noninvasive EMI techniques are well suited to assess the temporal and spatial variability of soil properties such as salinity (Johnston et al., 1997; Lesch et al., 1992; Rhoades et al., 1999; Triantafilis et al., 2000; Urdanoz and Aragüés, 2010; Wittler et al., 2006), water content (Brevik et al., 2006; Kachanoski et al., 1988), soil 
texture and depth-to-clay mapping (Doolittle et al., 1994; Saey et al., 2009), and in applications to precision agriculture (Corwin and Plant, 2005; Sudduth et al., 2001). Estimations of these soil properties from EC $\mathrm{E}_{\mathrm{a}}$ measurements are more suitable in areas with a single dominant soil factor, when variations in $\mathrm{EC}_{\mathrm{a}}$ response can be directly related to changes in the dominant property (Friedman 2005). Hence, EMI instruments are feasible tools for the appraisal of soil salinity at the irrigation district level if properly calibrated to provide low uncertainty in the predictive equations.

The objective of this work was to quantify soil salinity through EMI techniques and relate it to physical characteristics and irrigation management in four semiarid Mediterranean irrigation districts located in Morocco, Spain, Tunisia and Turkey. To achieve this, the following sub-objectives were envisaged: (1) analysis of EMI-soil salinity calibration equations, (2) assessment of normal and inverted EMI profiles to delineate potential shallow water table areas, (3) development of soil salinity maps from EMI surveys by integrating geographic information systems, and (4) establishment of relationships between soil salinity, physical characteristics and irrigation management.

\section{Materials and Methods}

\subsection{General characteristics of the study areas}

The names of the four Mediterranean irrigation districts studied are given in Table 1. For the purpose of simplicity, the names of the corresponding countries will be used in this work. Table 1 summarizes some relevant physical and management characteristics of the study areas.

Irrigation volumes (I) were provided by the respective Water User Associations or were measured in gauging stations constructed at the inlets and, if needed, outlets of the study areas. Precipitation (P) was measured in meteorological stations located within each district, and reference evapotranspiration (ETo $)_{0}$ was calculated with the FAO Penman-Monteith method (Allen et al., 1998) using the data gathered in these meteorological stations. Crop evapotranspiration $\left(\mathrm{ET}_{\mathrm{c}}\right.$ ) was calculated as $\mathrm{ET}_{\mathrm{c}}=\mathrm{ET}_{\mathrm{o}} \mathrm{K}_{\mathrm{c}}$, where $\mathrm{K}_{\mathrm{c}}$ are crop coefficients taken from local information or the literature (Allen et al., 1998). Drainage was measured in gauging stations constructed at both the inlets and outlets of each catchment to determine the net drainage flow $(Q)$ within each district and drainage water salinity (electrical conductivity, EC) was measured daily in water samples taken in these stations with automatic water samplers. Irrigation water EC was also measured 
in samples taken periodically. The ECs given in Table 1 are discharge-weighted average values for the given irrigation seasons.

From the inputs and outputs of water shown in Table 1, the following indexes were calculated

Leaching Fraction (LF), the percentage of irrigation $(\mathrm{I})$ and precipitation $(\mathrm{P})$ that percolates below the crop root zone:

$$
L F=100 \frac{(I+P-E T c)}{(I+P)}
$$

Drainage Fraction (DF), the percentage of irrigation $(\mathrm{I})$ and precipitation $(\mathrm{P})$ that exits the study area as drainage $(Q)$ :

$$
\mathrm{DF}=100 \frac{\mathrm{Q}}{(I+P)}
$$

Irrigation Efficiency (IE), the percentage of irrigation (I) that is evapotranspired by crops $\left(E T_{c}\right)$ discounting the effective precipitation $\left(P_{\text {ef }}\right)$ :

$$
\mathrm{IE}=100 \frac{\left(E T_{\mathrm{C}}-\mathrm{P}_{\mathrm{ef}}\right)}{\mathrm{I}}
$$

Irrigation Concentration Factor (ICF), the ratio of drainage water salinity $\left(\mathrm{EC}_{\text {drainage water }}\right)$ to irrigation water salinity $\left(\mathrm{EC}_{\text {irrigation water }}\right)$ :

$$
\mathrm{ICF}=\frac{\mathrm{EC}_{\text {drainage water }}}{\mathrm{EC}_{\text {irrigation water }}}
$$

Based on local information, the effective precipitation included in the IE index was taken as $75 \%$ of $P$ in Morocco, Spain and Tunisia (Cuenca, 1989), and 43\% of P in Turkey (Brouwer and Heibloem, 1986). Some information is missing in Table 1 for Morocco because some farmers use the drainage waters for irrigation and the flows at the exit of the irrigation district are negligible.

A short summary of some relevant characteristics of each study area follows.

Morocco: the 2600 ha Beni Amir irrigation district is located in the Tadla irrigation scheme (Oum Er Rbia River basin, 250 km south-east of Rabat, Morocco; latitude: $32^{\circ} 20^{\prime} \mathrm{N}$; longitude: $6^{\circ} 40^{\prime} \mathrm{W}$ ). The area has a Mediterranean climate characterized by annual average values of $350 \mathrm{~mm}$ (precipitation), $18.9{ }^{\circ} \mathrm{C}$ (air temperature) and 1796 mm (ETo). Irrigation started in 1938 using surface waters from the Ahmed El Hansali dam in the Oum Er Rbia River and groundwaters pumped from a large aquifer system. Drainage waters are 
also used by some farmers for irrigation purposes. The area consists of syncline depressions covered by heterogeneous mio-plio-quaternary deposits. This depression is constituted by a heterogeneous wavy bedding of conglomerates, white marls and lacustrine limestones surmounted by a red clay formation. The Oum Er Rbia River flows through a valley filled by homogeneous and fine-texture deposits. The predominant soil classes are iso-humic, clay to clay-silty and deep to moderately deep soils, and calci-magnesic, highly calcareous and shallow soils.

Spain: the 505 ha Lerma gully basin is located in the Bardenas II irrigation scheme (middle Ebro River basin, Zaragoza, Spain; latitude: $42^{\circ} 3^{\prime} 34.84^{\prime \prime} \mathrm{N}$; longitude: $1^{\circ} 8^{\prime} 2.86^{\prime \prime} \mathrm{W}$ ). The basin is located on the remains of glacis over Miocene marls high in limestone, gypsum and evaporitic salts that are the substrate of the basin. The glacis have a colluvium covering of variable thickness (1 to $2 \mathrm{~m}$ ) over the underlying marls. The soils (orthent and fluvent entisols) are shallow in the erosional slopes and deeper close to the gullies present in the basin, with a silty-clay-loam texture, and with salts derived from rock weathering. The soils over the glacis have a 2-3\% gentle slope, good internal drainage due to its loamy texture and stoniness (up to $60 \%$ ), are non saline, and show calcic and cambic horizons. The infiltration waters percolate through these soils, meet the underlying marls and dissolve and transport the salts towards the gullies. Irrigation in the area began in 2006 and the irrigated area in 2008 was $60 \%$ of the catchment area. The irrigation water is taken from the Bardenas Canal.

Tunisia: the 2905 ha Kalaât Landalous irrigation district is located in the lowest part of Mejreda River basin (latitude: $6^{\circ} 37^{\prime}$ and $37^{\circ} 2^{\prime} \mathrm{N}$; longitude: $10^{\circ} 5^{\prime}$ and $10^{\circ} 10^{\prime} \mathrm{E}$ ). The drainage outlet of this district is below sea level, and drainage waters are discharged to the Mediterranean Sea through a pumping station. The administrative limits of the study area are the Mediterranean Sea (east), the Mejreda River (north-west) and the drainage emissary of Henchir Tobias (south). The district is equipped with irrigation and drainage networks. The irrigation water is taken from the Mejreda River. The soils have a fine texture, ranging from silty-clay to clayey-silt. Most soils have $\mathrm{EC}_{\mathrm{e}}$ values above $2 \mathrm{dS} \mathrm{m}^{-1}$, and may reach values up to 8-10 $\mathrm{dS} \mathrm{m}^{-1}$ near to the south-east sebkha (playa lake). Shallow water tables of about $1.4 \mathrm{~m}$ depth are present in the lower parts of the district, with very high salinity values that make them unsuitable for irrigation or other municipal and industrial uses.

Turkey: the Akarsu Irrigation District is located between $36^{\circ} 57^{\prime} 32^{\prime \prime}$ and $36^{\circ} 50^{\prime} 43^{\prime \prime} \mathrm{N}$ latitudes and $35^{\circ} 40^{\prime} 22^{\prime \prime}$ and $35^{\circ} 28^{\prime} 42^{\prime \prime}$ E longitudes in Lower Seyhan Plain (LSP), named after the River Seyhan, in the Eastern part of the Mediterranean region, Turkey. The LSP covers a gross area of 213200 ha, of which 174088 ha are suitable for irrigation. The soils in the 9495 ha Akarsu Irrigation District are largely alluvial 


\section{5}

deposits of the Old River Terraces and Bajadas (Dinc et al., 1991) with high clay contents, varying from 51 to $77 \%$, that are predominantly swelling smectites. The soils generally have A and C horizons and, upon drying, 1-cm wide and 1-m deep cracks may develop. The area has been irrigated for over 40 years with appropriate irrigation and drainage infrastructures. The irrigation water is diverted from the Seyhan River. Presently, there are no soil salinity and sodicity problems in the district, and the main constraints to high crop yields are shallow groundwater and excess irrigation volumes. Irrigation efficiency in the area is very low, and irrigation management needs to be improved to prevent excess irrigation and thereby to decrease drainage discharge.

The hydrographic boundaries of the studied catchments were established in previous works or were delineated using a $20 \times 20 \mathrm{~m}$ Digital Elevation Model (DEM) and the ArcHydro application (ArcGIS 9.1, ESRI Inc., Redlands, CA, USA). This application defines the stream lines from the DEM and, after selecting the drainage outlets, automatically generates the corresponding catchment boundaries by linking together the pixels draining towards each outlet.

\subsection{EMI sensor readings}

Manual $\mathrm{EC}_{\mathrm{a}}$ readings were taken with a Geonics EM38 sensor (Geonics Inc., Mississauga, ON, Canada) in all study areas except Spain, where automatic readings with the Dualem 1 S sensor (Dualem Inc., Milton, ON, Canada) were taken using a mobile, geo-referenced EMI vehicle (Urdanoz et al., 2008). The Geonics EM38 has two coplanar transmitter and receiver coils, $1 \mathrm{~m}$ apart. The coils may be positioned parallel $(\mathrm{H}-\mathrm{H}$ orientation) or perpendicular (V-V orientation) to the earth's surface. The Dualem $1 \mathrm{~S}$ has three coils: one vertical transmitter coil and two receiver coils: vertical (coplanar, $1 \mathrm{~m}$ apart from the transmitter) and horizontal (perpendicular, $1.1 \mathrm{~m}$ apart from the transmitter) which provide for two simultaneous $\mathrm{EC}_{\mathrm{a}}$ readings ( $\mathrm{V}-\mathrm{V}$ and $\mathrm{V}-\mathrm{H}$, respectively). The depths of exploration for a $70 \%$ cumulative response in the $\mathrm{V}-\mathrm{V}$ mode (i.e., $\mathrm{EC}_{\mathrm{a}-\mathrm{v}}$ readings) are $1.55 \mathrm{~m}$ for the Geonics and Dualem, whereas they are $0.75 \mathrm{~m}$ for the Geonics $\mathrm{H}-\mathrm{H}$ and $0.50 \mathrm{~m}$ for the Dualem $\mathrm{V}-\mathrm{H}$ modes (Abdu et al., 2007). Depending on soil profile characteristics, these $\mathrm{H}-\mathrm{H}$ and $\mathrm{V}-\mathrm{H}$ readings could be somewhat different, but in practical terms both may be considered similar. For the purpose of simplicity, in this work the $\mathrm{H}-\mathrm{H}$ and $\mathrm{V}-\mathrm{H}$ readings will be referred as $\mathrm{EC}_{\mathrm{a}-\mathrm{h}}$, and the $\mathrm{V}-\mathrm{V}$ readings as $\mathrm{EC}_{\mathrm{a}-\mathrm{v}}$.

The total number of $\mathrm{EC}_{\mathrm{a}}$ readings taken in each study area ranged from 149 in Morocco to 556 in Spain. Table 2 gives some basic statistics of these readings. The EMI surveys were generally carried out two 


\section{列}

to three days after irrigation, so that soil water contents would be as uniform and close to field capacity as possible. Soil temperatures were recorded at each surveying time to convert the readings to a reference temperature of $25{ }^{\circ} \mathrm{C}$. The $\mathrm{EC}_{\mathrm{a}}$ readings were interpolated into a $15 \times 15 \mathrm{~m}$ regular grid by ordinary kriging (Goovaerts, 1997) using public domain SGeMS software (Remy, 2004) to facilitate further geographic and statistical analyses. All the $\mathrm{EC}_{\mathrm{a}}$ values are given in $\mathrm{dS}^{-1}$ at $25^{\circ} \mathrm{C}$.

Potential shallow water table areas were delineated through the $\mathrm{EC}_{\mathrm{a}-\mathrm{h}} / \mathrm{EC}_{\mathrm{a}-\mathrm{v}}$ ratios obtained from the EMI readings in each study area. Uniform $\left(0.9<\mathrm{EC}_{\mathrm{a}-\mathrm{h}} / \mathrm{EC}_{\mathrm{a}-\mathrm{v}}<1.1\right)$ and normal $\left(\mathrm{EC}_{\mathrm{a}-\mathrm{h}} / \mathrm{EC}_{\mathrm{a}-\mathrm{v}}<0.9\right) \mathrm{EC}_{\mathrm{a}}$ profiles indicate a net downward flux of water and salts, whereas inverted profiles $\left(\mathrm{EC}_{\mathrm{a}-\mathrm{h}} / \mathrm{EC}_{\mathrm{a}-\mathrm{v}}>1.1\right)$ are or can be related to a net upward flux of water and salts arising from shallow water tables (Rhoades et al., 1999).

\subsection{EMI sensor calibration}

A total of 18 to 34 evenly distributed calibration sites were selected with EMI readings along the full $\mathrm{EC}_{\mathrm{a}}$ interval in each district. The EMI sensors were calibrated against soil salinity (electrical conductivity of the soil saturation extract, $\mathrm{EC}_{\mathrm{e}}$ ) two to three days after irrigation by taking soil samples beneath the sensors immediately following the EMI readings at each site. The soil samples were taken, when permitted, at $0.3 \mathrm{~m}$ increments to a depth of $0.9 \mathrm{~m}$ in Morocco and Tunisia, $1.2 \mathrm{~m}$ in Spain and $2.0 \mathrm{~m}$ in Turkey. $\mathrm{EC}_{\mathrm{e}}$, saturation percentage (SP) and, except in Turkey, gravimetric soil water content (WC) were measured by standard methods (United States Salinity Laboratory Staff, 1954). Table 3 gives some basic statistics for these measurements. From the $\mathrm{EC}_{\mathrm{a}-\mathrm{h}}$ and $\mathrm{EC}_{\mathrm{a}-\mathrm{v}}$ readings and the soil profile average $\mathrm{EC}_{\mathrm{e}}$ values measured in each calibration site, the linear regressions between $\mathrm{EC}_{\mathrm{e}}$ and $\mathrm{EC}_{\mathrm{a}}$ were established in each study area (Table 4).

The relative effects of soil profile $\mathrm{EC}_{\mathrm{e}}$, texture (quantified through $\mathrm{SP}$ as given by Slavich and Petterson, 1993) and WC on $\mathrm{EC}_{\mathrm{a}-\mathrm{h}}$ were assessed through a multiple linear regression (MLR) analysis between the standardized $\mathrm{EC}_{\mathrm{e}}, \mathrm{SP}$ and $\mathrm{WC}$ independent variables and the standardized $\mathrm{EC}_{\mathrm{a}-\mathrm{h}}$ dependent variable (Table 5). The results obtained using $\mathrm{EC}_{\mathrm{a}-\mathrm{v}}$ as the dependent variable were qualitatively similar and are not shown. 
The interpolated $\mathrm{EC}_{\mathrm{a}}$ values were transformed to $\mathrm{EC}_{\mathrm{e}}$ by means of the site-specific $\mathrm{EC}_{\mathrm{a}}-\mathrm{EC}_{\mathrm{e}}$ calibration

equations. For simplicity, the $\mathrm{EC}_{\mathrm{e}}$ values estimated from $\mathrm{EC}_{\mathrm{a}-\mathrm{h}}$ and $\mathrm{EC}_{\mathrm{a}-\mathrm{v}}$ will be referred as $\mathrm{EC}_{\mathrm{e}-\mathrm{h}}$ and $\mathrm{EC}_{\mathrm{e}-\mathrm{v}}$, respectively. The $\mathrm{EC}_{\mathrm{e}-\mathrm{h}}$ maps of each study area (Fig. 1) were obtained using ArcGIS 9.1. The $\mathrm{EC}_{\mathrm{e}-\mathrm{v}}$ maps showed higher values than the $\mathrm{EC}_{\mathrm{e}-\mathrm{h}}$ maps, but their spatial patterns were similar and, therefore, they are not presented. From these maps, the percentage of the total irrigated areas falling into different $\mathrm{EC}_{\mathrm{e}-\mathrm{h}}$ intervals and the surface-weighted $\mathrm{EC}_{\mathrm{e}-\mathrm{h}}$ were calculated in each study area (Table 6).

\section{Results and Discussion}

3.1. General characteristics of the study areas

The study areas varied in irrigated area between a minimum of about 300 ha in Spain and a maximum of about 9500 ha in Turkey, amounting in all cases to more than $60 \%$ of the total catchment areas. Winter cereals were predominant in Morocco and Tunisia, and maize in Spain and Turkey. Surface irrigation was the main system, except in Spain and Tunisia where sprinkler irrigation was predominant. Irrigation efficiency (IE) was lowest in the surface-irrigated districts (IE $\leq 52 \%$ in Morocco and Turkey) and highest in the Spanish pressurized irrigation district ( $\mathrm{IE}=70 \%$ ). The Tunisian pressurized irrigation district appeared to have the lowest average IE (39\%), although a significant fraction of the area only had supplementary irrigation and calculating IE on a monthly basis increased the average value to $69 \%$.

Important differences were obtained in the main water inputs (I and $P$ ) and outputs $\left(E T_{c}\right.$ and $Q$ ) between the study areas and, consequently, between the leaching fraction (LF, minimum of $28 \%$ in Spain and maximum of $52 \%$ in Turkey) and the drainage fraction (DF, minimum of $13 \%$ in Spain and maximum of $48 \%$ in Turkey).

Irrigation water salinity was very low in Spain and Turkey $\left(E C_{i w}=0.4 \mathrm{dS} \mathrm{m}^{-1}\right)$, moderate in Morocco $\left(E C_{i w}=2.6 \mathrm{dS} \mathrm{m}^{-1}\right)$ and high in Tunisia $\left(E C_{\text {iw }}=3.6 \mathrm{dS} \mathrm{m}^{-1}\right)$. Cropping patterns responded to these irrigation salinity levels, so that maize, very sensitive to salinity, was dominant in Spain and Turkey whereas winter crops and forages, tolerant to salinity, were significant in Tunisia. 
Drainage water salinity was low to moderate in Turkey $\left.\left(E_{\mathrm{dw}}=1.4 \mathrm{dS} \mathrm{m}\right)^{-1}\right)$, high in Spain $\left(\mathrm{EC}_{\mathrm{dw}}=4.6\right.$

$\left.\mathrm{dS} \mathrm{m}^{-1}\right)$ and very high in Tunisia $\left(\mathrm{EC}_{\mathrm{dw}}=9.0 \mathrm{dS} \mathrm{m}^{-1}\right)$. In Morocco, an average $\mathrm{EC}_{\mathrm{dw}}$ could not be recorded because most drainage waters either deep-percolated or were used by farmers to irrigate winter crops. In addition the drainage ditch was used to purge the main irrigation canal when needed. For these reasons, the volume and salinity of drainage waters in Morocco are not reported in Table 1. Nevertheless, drainage water samples collected in some points along the drainage ditch in Morocco had an $\mathrm{EC}_{\mathrm{dw}}$ of around $2.6 \mathrm{dS} \mathrm{m}^{-1}$.

The irrigation concentration factor (ICF, ratio of $E_{d w}$ to $E C_{\text {iw }}$ ) reflects the evapo-concentration effect due to ET (i.e., the inverse of LF) and the weathering effect due to mineral dissolution (i.e., leaching of salts arising from weathered minerals occurring in the soil profile or deposited below) (Aragüés and Tanji, 2003). The ICF was highest in Spain (11.5) due to a low $28 \%$ LF and the presence of saline marls that are the substrate of the basin. Even though some soils were salt-affected, the lowest ICF was found in Tunisia (2.5) due to a high (48\%) LF. An unexpected and relatively high ICF of 3.5 was obtained in Turkey, even though LF $(52 \%)$ and DF (48\%) were high and soil salinity was low, suggesting that other undetermined sources of salts, most likely transported from the neighboring areas that increased the salinity of shallow groundwater, were present in this catchment. These ICF values should be treated with caution because the hydrogeology in these study areas is not well known and, as the example in Turkey shows, the $\mathrm{EC}_{\mathrm{dw}}$ could be influenced by the interception of groundwaters of variable salinity that will affect ICF.

\subsection{EMI sensor readings}

Table 2 summarizes some basic statistics of the $\mathrm{EC}_{\mathrm{a}-\mathrm{h}}$ and $\mathrm{EC}_{\mathrm{a}-\mathrm{v}}$ readings taken in each district. The $\mathrm{EC}_{\mathrm{a}}$ values were quite different between areas, with maximum values in Tunisia and minimum values in Spain and Morocco. The mean $\mathrm{EC}_{\mathrm{a}}$ values were also lowest in Morocco and Spain, and highest in Tunisia, with CV between 40\% (Tunisia) and 100\% (Spain). The medians were close to the means in Morocco and Turkey (i.e., the $\mathrm{EC}_{\mathrm{a}}$ distributions were not-skewed) and lower than the means in Spain and Tunisia (i.e., the $\mathrm{EC}_{\mathrm{a}}$ distributions were right-skewed).

The mean $\mathrm{EC}_{\mathrm{a}-\mathrm{h}}$ readings were lower than the mean $\mathrm{EC}_{\mathrm{a}-\mathrm{v}}$ readings, and most of the $\mathrm{EC}_{\mathrm{a}}$ profiles (i.e., $\left.E C_{a-h} / E C_{a-v}\right)$ were uniform or normal. These results suggest that the soils were generally subject to saltleaching. Spain was the only exception, where 19\% of the profiles were inverted. Most of these inverted profiles were close to gullies, and since they may be related to a net upward flux of water and salts (Rhoades 
et al., 1999), these areas should be further surveyed to determine whether shallow water tables are being developed. The lack of inverted $\mathrm{EC}_{\mathrm{a}}$ profiles in Tunisia was apparently inconsistent, since shallow water tables were present in the lower south-east areas of the district. However, these water tables were highly saline due to sea water intrusion, so that $\mathrm{EC}_{\mathrm{a}-\mathrm{v}}$ would be higher than $\mathrm{EC}_{\mathrm{a}-\mathrm{h}}$ (i.e., normal instead of inverted profiles) because of the larger depth of exploration of the $\mathrm{V}-\mathrm{V}$ readings that will penetrate deeper in these highly saline water tables. In these cases, $\mathrm{EC}_{\mathrm{a}}$ profiles would not be suitable to characterize the flux of water and salts in the soil profile.

\subsection{EMI sensor calibration}

Table 3 shows for each district the number of sampling points for EMI calibration, the number of total soil samples analyzed, and some basic statistics for soil profile average gravimetric water content (WC), saturation percentage $(\mathrm{SP})$ and saturation extract $E C\left(E C_{\mathrm{e}}\right)$. WC was not measured in Turkey, but previous information shows that WC at field capacity is very high (close to $35 \%$ ) due to the presence and redundancy of swelling smectite clay minerals. Since the calibration surveys were usually performed two to three days after irrigation, this value of $35 \%$ will be representative of actual soil water contents at the time of measurement. In the other study areas, mean WC varied between $16 \%$ (Spain) and $25 \%$ (Tunisia). These values were in agreement with mean SP values, maximum in Turkey (99\%) and minimum in Spain (41\%). Soil texture was not measured, but the SP values indicate that the textural grades vary between heavy clays in Turkey and loam to silty-clay-loam in Spain (Slavich and Petterson, 1993). Based on the CV of the mean SP and WC values, soil textures and soil water contents of the samples taken were considered relatively uniform (CV values below 25\%).

Soil salinity $\left(\mathrm{EC}_{\mathrm{e}}\right)$ was quite variable within and between districts, with maximum values close to 15 $\mathrm{dS} \mathrm{m}^{-1}$, minimum values below $1 \mathrm{dS}^{-1}$, and $\mathrm{CV}$ values between $37 \%$ (Morocco) and 105\% (Spain). Although the mean $\mathrm{EC}_{\mathrm{e}}$ for the relatively low number of sampling points may not be representative of actual soil salinity in the study areas, the ranking will be (Table 3): Tunisia > Spain > Morocco > Turkey. Except in Morocco, the means were higher than the medians, showing that the $\mathrm{EC}_{\mathrm{e}}$ distributions were skewed to the right. These skewed distributions were a consequence of the sampling strategy and the physical and management characteristics of the districts. 
The $E C_{a}-E C_{e}$ calibration equations were highly significant $(P<0.001)$ in all the study areas, with $R^{2}$ values close to or above 0.8 (Table 4). The $R^{2}$ values were generally lower for $E C_{a-v}$ than for $E C_{a-h}$, an expected result since the depth of exploration in the $\mathrm{V}-\mathrm{V}$ dipole configuration (i.e., $\mathrm{EC}_{\mathrm{a}-\mathrm{v}}$ ) is higher than the depth of soil sampling. The regression coefficients ("a" values in Table 4) were relatively similar in Morocco, Spain and Tunisia, and much lower in Turkey. The intercepts ("b" values in Table 4) were not significantly different from zero $(P>0.05)$ in all the study areas except in Tunisia. These results show that the calibration equations are site-specific and must be developed for the particular soils of interest.

Many studies have shown that $\mathrm{EC}_{\mathrm{a}}$ is generally influenced by $\mathrm{EC}_{\mathrm{e}}$ but, depending on soil characteristics, may also be affected by WC, texture, bulk density and temperature (Corwin and Lesch, 2005; Hanson and Kaita, 1997; McKenzie et al., 1989; Urdanoz and Aragüés, 2010). The relative effects of $\mathrm{EC}_{\mathrm{e}}$, WC and SP (texture) on $\mathrm{EC}_{\mathrm{a}}$ were determined through a multiple linear regression (MLR) analysis of the corresponding standardized variables (Table 5). $\mathrm{EC}_{a-h}$ was significantly correlated $(P<0.001)$ with $\mathrm{EC}_{\mathrm{e}-\mathrm{h}}$ in all the study areas, with coefficients varying between 1.01 (Tunisia) and 0.23 (Morocco). EC $\mathrm{ah}_{\mathrm{h}}$ was not significantly correlated $(P>0.1)$ with WC because the sampling strategy (soil samples taken at or close to field capacity) provided a relatively low $\mathrm{CV}$ of this variable (Table 3). In contrast, $\mathrm{EC}_{\mathrm{a}}$ and $\mathrm{WC}$ have been found to be positively correlated in other studies (Hanson and Kaita, 1997; Rhoades et al., 1999; Wittler et al., 2006), although excess soil moisture may also reduce $\mathrm{EC}_{\mathrm{a}}$ due to a dilution of the electrolytes present in the soil solution (McKenzie et al. 1989). Soil texture (SP) was positively and significantly correlated with $\mathrm{EC}_{\mathrm{a}-}$ $h$ in Spain $(P<0.1)$ and Turkey $(P<0.01)$, in agreement with previous works (Brevik et al., 2006; Doolittle et al., 1994). In contrast, soil texture was not significantly correlated $(P>0.1)$ with $E_{a-h}$ in Morocco and Tunisia. Wittler et al. (2006) also found that the soil textural class was not a significant explanatory variable. Thus, the effects of soil water content and soil texture on $\mathrm{EC}_{\mathrm{a}}$ were site-specific and should be determined in each study area.

The MLR analysis showed that the $\mathrm{EC}_{\mathrm{e}-\mathrm{h}}$ coefficients ("a" in Table 5) were much higher than the SP coefficients ("c" in Table 5) in all districts except Turkey, although the Turkish case was not comparable to the other study areas because WC could not be included in the MLR analysis. These results indicate that $E C_{a-h}$ was mostly affected by $E C_{e-h}$, so that the $E C_{e-h}$ maps obtained from the interpolated $E C_{a-h}$ values and the site-specific $\mathrm{EC}_{\mathrm{a-h}}$ vs. $\mathrm{EC}_{\mathrm{e}-\mathrm{h}}$ calibration equations could be used effectively to assess soil salinity and its spatial variability in these irrigation districts. 
The $\mathrm{EC}_{\mathrm{e}-\mathrm{h}}$ maps (Fig. 1) indicate that the spatial variability of soil salinity was relatively low in Morocco, Spain and Turkey and relatively high in Tunisia. The differences in $\mathrm{EC}_{\mathrm{e}-\mathrm{h}}$ observed in Morocco between the central-northern and the southern areas were attributed to the nature of the soils and different geology. In Morocco, $84 \%$ of the total irrigated area was within the 1.7 to $2.6 \mathrm{dS} \mathrm{m}^{-1} \mathrm{EC}_{\mathrm{e}-\mathrm{h}}$ interval (Table 6). The variability in Spain was attributed to the differential geomorphology, with uniform and low EC e-h $_{\text {soils }}$ located over the glacis and more irregular and higher $\mathrm{EC}_{\mathrm{e}-\mathrm{h}}$ soils located in areas with shallower saline marls close to some gullies in the south of the study area. In Spain, $86 \%$ of total irrigated area had $\mathrm{EC}_{\mathrm{e}-\mathrm{h}}$ values below $2.0 \mathrm{dS} \mathrm{m}^{-1}$ (Table 6). In Tunisia, the high $\mathrm{EC}_{\mathrm{e}-\mathrm{h}}$ soils observed in the south-east area were mainly due to sea water intrusion derived from its low elevation and proximity to the sea, whereas the high $\mathrm{EC}_{\mathrm{e}-\mathrm{h}}$ soils present in the north-east were attributed to typical high irrigation efficiencies in drip-irrigated forages and vegetable crops. The high soil salinity variability in Tunisia is also reflected by the high percentages of total irrigated area in each $\mathrm{EC}_{\mathrm{e}-\mathrm{h}}$ interval (Table 6). The variability in Turkey could most likely be attributed to the wide range of different irrigation systems, the changes of cropping patterns taking place during the irrigation season and the observed spatial variability of groundwater depths with varying salinity. In Turkey, $86 \%$ of total irrigated area had $\mathrm{EC}_{\mathrm{e}-\mathrm{h}}$ values below $0.54 \mathrm{dS} \mathrm{m}^{-1}$ (Table 6).

The surface-weighted average $E C_{e-h}$ values $\left(E C_{e-h-s w a}\right.$ in Table 6$)$ varied between $3.4 \mathrm{dS} \mathrm{m}^{-1}$ in Tunisia and $0.45 \mathrm{dS} \mathrm{m}^{-1}$ in Turkey, with intermediate values in the other districts. Based on these values and the salinity tolerance (Maas and Hoffman, 1977) of the most important crops grown in each study area, average expected yield decreases would only be significant for vegetables cropped in Tunisia, and would be irrelevant in the remaining districts. The $\mathrm{EC}_{\text {e-h-swa }}$ ranking for the study areas was Tunisia $>$ Morocco $>$ Spain $>$ Turkey. This ranking was similar to the ranking given by the measured mean $\mathrm{EC}_{\mathrm{e}}$ values (Table 3 ) in Tunisia and Turkey, but was different in Morocco and Spain, showing that salinity values based on a limited number of soil samples could deviate from salinity estimates that more precisely take into account its irrigation-district spatial variability.

A comparison of soil salinity with the general characteristics of the districts (Table 1) showed that it was positively correlated $\left(R^{2}=0.878 ; P<0.06\right)$ with irrigation water salinity $\left(E C_{\text {iw }}\right)$. The addition of $I E$ (irrigation efficiency) in an MLR analysis increased the coefficient of determination to 0.995 (significant at $\mathrm{P}<$ 0.05):

$$
\mathrm{EC}_{\text {e-h-swa }}\left(\mathrm{dS} \mathrm{m}^{-1}\right)=-1.7+0.68 \mathrm{EC}_{\text {iw }}\left(\mathrm{dS} \mathrm{m}^{-1}\right)+0.04 \mathrm{IE}(\%)
$$

The inclusion in the MLR analysis of leaching (LF) and/or drainage (DF) fractions did not increase its significance. Although the low number of studied districts was insufficient to obtain sound conclusions, this 
relationship consistently showed that soil salinity in these districts was mostly affected by irrigation salinity, followed by the efficiency of irrigation. Leaching and/or drainage fractions were not correlated with soil salinity, probably because they were obtained from hydrological variables (I and Q) with some measurement uncertainties in certain districts as Morocco and Tunisia.

Drainage water salinity $\left(E_{\mathrm{dw}}\right)$ measured at the exit of each irrigation district (Table 1$)$ was positively correlated with soil salinity $\left(R^{2}=0.72\right)$ and irrigation efficiency $\left(R^{2}=0.67\right)$, although they were only significant at $P<0.4$. The MLR of $E C_{d w}$ on both variables was significant at $P<0.2$ :

$$
E C_{d w}\left(d S m^{-1}\right)=-8.2+1.55 E C_{\text {e-h-swa }}\left(d S m^{-1}\right)+0.16 \text { IE }(\%) ; R^{2}=0.92
$$

The highest $E C_{d w}$ values measured in Tunisia $\left(9.0 \mathrm{dS} \mathrm{m}^{-1}\right)$ and Spain $\left(4.6 \mathrm{dS} \mathrm{m}^{-1}\right)$ were also a consequence of the shallow and saline water tables present in some areas in Tunisia and of the saline marls that form the substrate of the basin in Spain. Hence, besides soil salinity and irrigation efficiency, hydrogeology and geomorphology also played an important role in the salinity of drainage waters in these districts.

In terms of salt loads in irrigation return flows $(\mathrm{IRF})$, both salinity $\left(E C_{d w}\right)$ and volume $(Q)$ of drainage waters must be quantified. The Tunisian district had the highest IRF salt load due to both high $E C_{d w}$ and $Q$ values, whereas the Spanish district, despite its relatively high $\mathrm{EC}_{\mathrm{dw}}$, had the lowest IRF-salt load due to its low $\mathrm{Q}(118 \mathrm{~mm})$. Although $\mathrm{EC}_{\mathrm{dw}}$ in the Turkish district was three times lower than in Spain, its IRF salt load was almost twice that of Spain due to its very high $Q(780 \mathrm{~mm})$. The quantification of these figures is essential to assess off-site salt pollution induced by irrigated agriculture, since salt load rather than salt concentration is the critical variable to quantify salinity build-up in the receiving water bodies (Aragüés and Tanji, 2003). Whereas salinity of irrigation return flows depends to a large extent on the sources of salts in irrigation waters, soils and geologic materials that cannot be significantly minimized through human intervention, the volume of irrigation return flows may be properly controlled through efficient water management at the delivery, conveyance, distribution and field-application levels. Our results show that a better water management to alleviate off-site salt-pollution problems should be implemented in Tunisia and Turkey, the two districts with higher IRF salt loads.

\section{Conclusions}


The EMI surveys performed in each irrigation district studied provided mean $\mathrm{EC}_{\mathrm{a}}$ values that were

lowest in Morocco and Spain, intermediate in Turkey and highest in Tunisia. With the exception of Spain, where $19 \%$ of the $\mathrm{EC}_{\mathrm{a}}$ profiles were inverted, the rest of the profiles were uniform or normal, suggesting that the soils were subject to a net downward flux of water and salts. However, the shallow and saline water tables present in some low-lying areas in Tunisia were not detected by this profile analysis, showing the limitations and site-specific results of this assessment.

$\mathrm{EC}_{\mathrm{a}}$ was significantly correlated $(\mathrm{P}<0.001)$ with $\mathrm{EC}_{\mathrm{e}}$, but not with soil water content and soil texture at this probability level. Hence, the $\mathrm{EC}_{\mathrm{e}}$ maps obtained in each district from the interpolated $\mathrm{EC}_{\mathrm{a}}$ values and the $E C_{a}-E C_{e}$ calibrations were a sensible approach for the assessment of salinity at the irrigation district scale. Soil salinity and its spatial variability was relatively low in all districts except Tunisia, where some lowlying areas in the south-east were affected by sea water intrusion and shallow water tables that raised soil salinity to EC values above $5 \mathrm{dS} \mathrm{m}^{-1}$. The ranking of districts based on the surface-weighted average $\mathrm{EC}_{\mathrm{e}}$ values calculated from these maps, and on the mean $\mathrm{EC}_{\mathrm{e}}$ values measured in 18 to 34 soil samples taken in each district was different for Morocco and Spain, showing that salinity values based on a limited number of soil samples could deviate from salinity estimates that take into account more precisely its spatial variability.

Irrigation district soil salinity consistently depended on irrigation water salinity and irrigation efficiency (IE), but not on the rest of the analyzed variables. Furthermore, drainage water salinity $\left(E_{\mathrm{dw}}\right)$ measured at the exit of each district consistently depended on soil salinity and irrigation efficiency (IE). Thus, IE was a significant variable negatively affecting soil and drainage water salinity concentrations.

However, since salt loads in irrigation return flows are a function of both the salinity $\left(\mathrm{EC}_{\mathrm{dw}}\right)$ and the volume $(\mathrm{Q})$ of drainage waters, and this volume depends to a large extent on the district irrigation efficiency, the lowest salt loads were obtained in Spain (high $\mathrm{EC}_{\mathrm{dw}}$ but very low $\mathrm{Q}$ ), intermediate in Turkey (low $\mathrm{EC}_{\mathrm{dw}}$ but very high $\mathrm{Q}$ ) and highest in Tunisia (very high $\mathrm{EC}_{\mathrm{dw}}$ and high $\mathrm{Q}$ ) while no $\mathrm{Q}$ data was available for Morocco. Therefore, the reduction of these high drainage volumes in Tunisia and Turkey through sound irrigation management and higher irrigation efficiencies will be the most efficient strategy to control the off-site saltpollution induced by these Mediterranean irrigation districts.

\section{Acknowledgments}


This study was supported by the European Commission research project INCO-CT-2005-015031.

2 The authors gratefully acknowledge the assistance of the technicians and students that actively participated 3 in this work.

\section{References}

6

Abdu, H., Robinson, D.A., Jones, S.B., 2007. Comparing bulk soil electrical conductivity determination using the DUALEM-1S and EM38-DD electromagnetic induction instruments. Soil Sci. Soc. Am. J. 71, 189196.

Allen, R.G., Pereira, L.S., Raes, D., Smith, M., 1998. Crop evapotranspiration-guidelines for computing crop water requirements. FAO Irrig. Drain. Paper 56, Rome, Italy.

Aragüés, R., Tanji, K.K., 2003. Water quality of irrigation return Flows. Encyclopedia of Water Science, Stewart B. A., Howell T. A. (Eds.), Marcel Dekker, NY, USA. pp. 502-506.

Brevik, E.C., Fenton, T.E., Lazari, A., 2006. Soil electrical conductivity as a function of soil water content and implications for soil mapping. Precis. Agric. 7, 393-404.

Brouwer, C., Heibloem, M., 1986. Irrigation Water Management: Irrigation Water Needs. FAO Irrigation Water Management Training Manual no. 3, FAO Land and Water Development Division, Rome, Italy.

Çetin, M., Diker, K., 2003. Assessing drainage problem areas by GIS: a case study in the Eastern Mediterranean Region of Turkey. Irrig. Drain. 52, 343-353.

Corwin, D.L., Lesch, S.M., 2005. Apparent soil electrical conductivity measurements in agriculture. Comput. Electron. Agr. 46, 11-43.

Corwin, D.L., Plant, R.E., 2005. Applications of apparent soil electrical conductivity in precision agriculture. Comput. Electron. Agr. 46, 1-10.

Cuenca, R.H., 1989. Irrigation system design. An engineering approach. Prentice Hall, Englewood Cliffs, New Jersey, p. 552.

Dinc, U., Şenol, S., Kapur, S., Sari, M., 1991. Catenary soil relationships in the Çukurova Region, southern Turkey. Catena 18, 185-196. 
Doolittle, J.A., Sudduth, K.A., Kitchen, N.R., 1994. Estimating depths to claypans using electromagnetic induction methods. J. Soil Water Conserv. 49, 572-575.

Friedman, S.P., 2005. Soil properties influencing apparent electrical conductivity: A review. Comput. Electron. Agr. 46, 45-70.

Goovaerts, P. 1997. Geostatistics for natural resources evaluation. Oxford University Press, New York. 483 $\mathrm{pp}$

Hanson, B.R., Kaita, K., 1997. Response of electromagnetic conductivity meter to soil salinity and soil-water content. J. Irrig. Drain. Eng. 123, 141-143.

Johnston, M.A., Savage, M.J., Moolman, J.H., du Plessis, H.M., 1997. Evaluation of Calibration Methods for Interpreting Soil Salinity from Electromagnetic Induction Measurements. Soil Sci. Soc. Am. J. 61, $1627-1633$.

Kachanoski, R.G., Gregorich, E.G., Van Wesenbeeck, I.J., 1988. Estimating spatial variations of soil water using noncontacting electromagnetic inductive methods. Can. J. Soil Sci. 68, 715-722.

Lal, R, Stewart, B.A., 1990. Soil degradation. Advances in Soil Science, Springer-Verlag, New York, NY.

Lesch, S.M., Rhoades, J.D., Lund, L.J., Corwin, D.L., 1992. Mapping Soil Salinity Using Calibrated Electromagnetic Measurements. Soil Sci. Soc. Am. J. 56, 540-548.

Maas, E.V., Hoffman, G.J., 1977. Crop salt tolerance: current assessment. J. Irrig. Drain. Div., Am. Soc. Civil Eng. 103, 115-134.

McKenzie, R.C., Chomistek, W., Clark, N.F., 1989. Conversion of electromagnetic inductance readings to saturated paste extract values in soils for different temperature, texture and moisture conditions. Can. J. Soil Sci. 69, 25-32.

Remy, N., 2004. The Stanford geostatistical earth modeling software (SGeMS): a tool for new algorithm development. In: Proceedings of the 7th Annual Geostatistics Congress, Banff, Alberta, Canada, pp. 865-871.

Rhoades, J.D., Chanduvi, F., Lesch, S., 1999. Soil salinity assessment. Methods and interpretation of electrical conductivity measurements. FAO Irrig. Drain. Paper 57, Rome, Italy.

Saey, T., Simpson, D., Vermeersch, H., Cockx, L., Van Meirvenne, M., 2009. Comparing the EM38DD and DUALEM-21S Sensors for Depth-to-Clay Mapping. Soil Sci. Soc. Am. J. 73, 7-12. 
Slavich, P.G., Petterson, G.H., 1993. Estimating the electrical conductivity of saturated paste extracts from 1:5 soil:water suspensions and texture. Aust. J. Soil Res. 31, 73-81.

Sudduth, K.A., Drummond, S.T., Kitchen, N.R., 2001. Accuracy issued in electromagnetic induction sensing of soil electrical conductivity for precision agriculture. Comput. Electron. Agr. 31, 239-264.

Triantafilis, J., Laslett, G.M., McBratney, A.B., 2000. Calibrating an electromagnetic induction instrument to measure salinity in soil under irrigated cotton. Soil Sci. Soc. Am. J. 64, 1009-1017.

Urdanoz, V., Amézketa, E., Clavería, I., Ochoa, V., Aragüés, R., 2008. Mobile and georeferenced electromagnetic sensors and applications for salinity assessment. Span. J. Agric. Res. 6, 469-478.

Urdanoz, V., Aragüés, R., 2010. Pre- and post-irrigation mapping of soil salinity with EMI techniques and relationships with drainage water salinity. Soil Sci. Soc. Am. J. (in press).

United States Salinity Laboratory Staff, 1954. Diagnosis and improvement of saline and alkali soils. Agric. Handbook 60, U.S. Dept. of Agriculture, Washington D.C.

Wittler, J.M., Cardon, G.E., Gates, T.K., Cooper, C.A., Sutherland, P.L., 2006. Calibration of electromagnetic induction for regional assessment of soil water salinity in an irrigated valley. J. Irrig. Drain. Eng. 132, 436-444.

Wood, S., Sebastian, K., Scherr, S.J., 2000. Soil resource condition. In: Wood S., Sebastian K., Scherr S.J . (Eds.), Pilot Analysis of Global Ecosystems. IFPRI and World Resources Institute, Washington, DC.

Zalidis, G., Stamatiadis, S., Takavakoglou, V., Eskridge, K., Misopolinos, N., 2002. Impacts of agricultural practices on soil and water quality in the Mediterranean region and proposed assessment methodology. Agr. Ecosyst. Environ. 88, 137-146. 
1 Table 1. General characteristics of the irrigation districts studied in each Mediterranean country.

\begin{tabular}{|c|c|c|c|c|}
\hline & MOROCCO & SPAIN & TUNISIA & TURKEY \\
\hline Name of irrigation district & Beni Amir & Lerma & Kalaât Landalous & Akarsu \\
\hline Irrigation season year & 2009 & 2008 & 2009 & 2008 \\
\hline Catchment area (ha) & 2600 & 505 & 2905 & 9495 \\
\hline Irrigated area (ha) & 2084 & 302 & 2312 & 9495 \\
\hline $\begin{array}{l}\text { Irrigation systems } \\
(\% \text { of total })^{\mathrm{a}}\end{array}$ & SU $(100 \%)$ & $\begin{array}{l}\text { SP }(90 \%) \\
\text { DR }(10 \%)\end{array}$ & $\begin{array}{l}\text { SP }(65 \%) \\
\text { DR }(35 \%)\end{array}$ & $\begin{array}{l}\text { SU (74\%), DR } \\
(20 \%), \text { SP }(6 \%)\end{array}$ \\
\hline $\begin{array}{l}\text { Main irrigated crops } \\
(\% \text { of total })^{b}\end{array}$ & $\begin{array}{l}\text { WC (40\%), AL } \\
(34 \%), \mathrm{OL}(15 \%) \text {, } \\
\text { OT (11\%) }\end{array}$ & $\begin{array}{l}\text { MA }(49 \%), \text { WC } \\
(25 \%), \text { VE }(21 \%) \text {, } \\
\text { OT }(5 \%)\end{array}$ & $\begin{array}{l}\text { WC (37\%), VE } \\
(33 \%), \text { FO } \\
(29 \%), \text { OT }(1 \%)\end{array}$ & $\begin{array}{l}\text { MA (41\%), Cl } \\
(29 \%), \text { WC } \\
(18 \%), \text { OT }(12 \%)\end{array}$ \\
\hline Irrigation (I, mm) & 773 & 529 & 1187 & 1105 \\
\hline Precipitation (P, mm) & 519 & 361 & 676 & 524 \\
\hline Reference $\mathrm{ET}(\mathrm{ET}, \mathrm{mm})$ & 1432 & 1069 & 1412 & 1128 \\
\hline Crop ET $\left(\mathrm{ET}_{\mathrm{c}}, \mathrm{mm}\right)$ & 793 & 642 & 975 & 779 \\
\hline Surface drainage $(Q, m m)$ & -- & 118 & 411 & 780 \\
\hline Leaching fraction (LF, \%) & 39 & 28 & 48 & 52 \\
\hline Drainage fraction (DF, \%) & -- & 13 & 22 & 48 \\
\hline Irrigation efficiency (IE, \%) & 52 & 70 & 39 & 50 \\
\hline EC irrigation water $\left(\mathrm{dS} \mathrm{m}^{-1}\right)$ & $2.6^{\mathrm{c}}$ & 0.4 & 3.6 & 0.4 \\
\hline EC drainage water $\left(\mathrm{dS} \mathrm{m}^{-1}\right)$ & -- & 4.6 & 9.0 & 1.4 \\
\hline Irrig.conc. factor (ICF) & -- & 11.5 & 2.5 & 3.5 \\
\hline
\end{tabular}

2 DDR: drip; SP: sprinkler; SU: surface

$3 \quad{ }^{\mathrm{b}} \mathrm{AL}$ : alfalfa; $\mathrm{Cl}$ : citrus; FO: forages; FT: fruit trees; MA: maize; OL: olive; OT: others; VE: vegetables;

$4 \quad$ WC: winter cereals

$5 \quad$ Volume-weighted average of the three sources of irrigation water: canal water, drainage water and 6 groundwater 
1 Table 2. Basic statistics of $E M I$ soil apparent $E C_{a}$ readings $\left(E C_{a-h}\right.$, horizontal; $E C_{a-v}$, vertical) taken in each 2 Mediterranean irrigation district. $\mathrm{N}=$ number of $\mathrm{EC}_{\mathrm{a}}$ readings. The percent of total uniform, normal and 3 inverted $\mathrm{EC}_{\mathrm{a}}$ profiles are also given.

\begin{tabular}{|c|c|c|c|c|c|c|c|c|}
\hline & \multicolumn{2}{|c|}{ MOROCCO } & \multicolumn{2}{|c|}{ SPAIN } & \multicolumn{2}{|c|}{ TUNISIA } & \multicolumn{2}{|c|}{ TURKEY } \\
\hline & $E C_{a-h}$ & $\mathrm{EC}_{\mathrm{a}-\mathrm{v}}$ & $E C_{a-h}$ & $E C_{a-v}$ & $E C_{a-h}$ & $E C_{a-v}$ & $E C_{a-h}$ & $E C_{a-v}$ \\
\hline & \multicolumn{8}{|c|}{ dS m ${ }^{-1}$ at $25^{\circ} \mathrm{C}$} \\
\hline $\mathrm{N}$ & \multicolumn{2}{|c|}{149} & \multicolumn{2}{|c|}{556} & \multicolumn{2}{|c|}{200} & \multicolumn{2}{|c|}{162} \\
\hline Maximum & 1.06 & 1.31 & 3.47 & 4.36 & 4.65 & 5.78 & 2.94 & 3.33 \\
\hline Minimum & 0.01 & 0.03 & 0.05 & 0.00 & 0.66 & 0.91 & 0.13 & 0.26 \\
\hline Mean & 0.42 & 0.49 & 0.41 & 0.62 & 1.51 & 1.93 & 0.78 & 1.06 \\
\hline CV (\%) & 43 & 45 & 108 & 106 & 39 & 40 & 52 & 45 \\
\hline Median & 0.42 & 0.49 & 0.20 & 0.34 & 1.36 & 1.71 & 0.74 & 0.99 \\
\hline \multicolumn{9}{|c|}{$E C_{a}$ profiles (\% of total) } \\
\hline Uniform $^{a}$ & \multicolumn{2}{|c|}{19} & \multicolumn{2}{|c|}{73} & \multicolumn{2}{|c|}{1} & \multicolumn{2}{|c|}{1} \\
\hline Normal $^{b}$ & \multicolumn{2}{|c|}{76} & \multicolumn{2}{|c|}{8} & \multicolumn{2}{|c|}{99} & \multicolumn{2}{|c|}{99} \\
\hline Inverted $^{c}$ & \multicolumn{2}{|c|}{5} & \multicolumn{2}{|c|}{19} & \multicolumn{2}{|c|}{0} & \multicolumn{2}{|c|}{0} \\
\hline \multicolumn{9}{|c|}{${ }^{\mathrm{a}} 0.9<\mathrm{EC}_{\mathrm{a}-\mathrm{h}} / \mathrm{EC}_{\mathrm{a}-\mathrm{v}}<1.1$} \\
\hline \multicolumn{9}{|c|}{${ }^{\mathrm{b}} \mathrm{EC}_{\mathrm{a}-\mathrm{h}} / \mathrm{EC}_{\mathrm{a}-\mathrm{v}}<0.9$} \\
\hline \multicolumn{9}{|c|}{${ }^{\circ} E C_{a-h} / E C_{a-v}>1.1$} \\
\hline
\end{tabular}


1 Table 3. Number of sampling points for EMI sensor calibration, number of total samples and basic statistics 2 of soil-profile average gravimetric water content (WC), saturation percentage (SP) and saturation extract EC $3 \quad\left(E C_{e}\right)$ in each Mediterranean irrigation district.

\begin{tabular}{|c|c|c|c|c|c|c|c|c|c|c|c|c|}
\hline & \multicolumn{3}{|c|}{ MOROCCO } & \multicolumn{3}{|c|}{ SPAIN } & \multicolumn{3}{|c|}{ TUNISIA } & \multicolumn{3}{|c|}{ TURKEY } \\
\hline & $\begin{array}{l}\text { WC } \\
(\%)\end{array}$ & $\begin{array}{l}\text { SP } \\
(\%)\end{array}$ & $\begin{array}{c}E C_{e} \\
\left(d S m^{-1}\right)\end{array}$ & $\begin{array}{l}\text { WC } \\
(\%)\end{array}$ & $\begin{array}{l}\text { SP } \\
(\%)\end{array}$ & $\begin{array}{c}E C_{e} \\
\left(d S m^{-1}\right)\end{array}$ & $\begin{array}{l}\text { WC } \\
(\%)\end{array}$ & $\begin{array}{l}\text { SP } \\
(\%)\end{array}$ & $\begin{array}{c}E C_{e} \\
\left(d S m^{-1}\right)\end{array}$ & $\begin{array}{l}\text { WC } \\
(\%)\end{array}$ & $\begin{array}{l}\text { SP } \\
(\%)\end{array}$ & $\begin{array}{c}E C_{e} \\
\left(d S ~ m^{-1}\right)\end{array}$ \\
\hline $\mathrm{N}^{\circ}$ of sampling points & \multicolumn{3}{|c|}{29} & \multicolumn{3}{|c|}{34} & \multicolumn{3}{|c|}{18} & \multicolumn{3}{|c|}{20} \\
\hline $\mathrm{N}^{\circ}$ of total samples & \multicolumn{3}{|c|}{87} & \multicolumn{3}{|c|}{108} & \multicolumn{3}{|c|}{54} & \multicolumn{3}{|c|}{120} \\
\hline Max & 40.2 & 57 & 3.3 & 24.2 & 58 & 15.3 & 36.9 & 97 & 14.3 & -- & 126 & 0.75 \\
\hline Min & 9.0 & 29 & 0.59 & 9.1 & 26 & 0.54 & 16.9 & 38 & 0.65 & -- & 56 & 0.29 \\
\hline Mean & 21.5 & 44 & 1.9 & 15.9 & 41 & 3.8 & 25.3 & 58 & 5.7 & $34.6^{a}$ & 99 & 0.49 \\
\hline CV (\%) & 15 & 17 & 37 & 24 & 21 & 105 & 21 & 23 & 74 & $5^{a}$ & 24 & 24 \\
\hline Median & 21.6 & 44 & 2.0 & 15.5 & 40 & 1.8 & 24.1 & 56 & 4.6 & -- & 106 & 0.46 \\
\hline
\end{tabular}

$4 \quad{ }^{a}$ Estimates based on soil water content measured at field capacity in four soil samples 
Table 4. EMI sensor calibration performed in each Mediterranean irrigation district: number of calibration 2 points $(\mathrm{N})$ and linear regression equations of soil-profile average saturation extract $E C\left(E C_{e}\right)$ against $E M I$ 3 soil apparent EC ( $\mathrm{EC}_{\mathrm{a}-\mathrm{h}}$, horizontal; $\mathrm{EC}_{\mathrm{a}-\mathrm{v}}$, vertical).

\begin{tabular}{|c|c|c|c|c|c|c|c|c|c|c|c|c|c|c|c|c|}
\hline & \multicolumn{16}{|c|}{$E C_{e}\left(d S m^{-1}\right)=a E C_{a}\left(d S m^{-1}\right)+b$} \\
\hline & \multicolumn{4}{|c|}{ MOROCCO } & \multicolumn{4}{|c|}{ SPAIN } & \multicolumn{4}{|c|}{ TUNISIA } & \multicolumn{4}{|c|}{ TURKEY } \\
\hline & $\mathrm{N}$ & a & b & $\mathrm{R}^{2}$ & $\mathrm{~N}$ & a & $\mathrm{b}$ & $\mathrm{R}^{2}$ & $\mathrm{~N}$ & a & b & $\mathrm{R}^{2}$ & $\mathrm{~N}$ & a & b & $\mathrm{R}^{2}$ \\
\hline $\mathrm{EC}_{\mathrm{a}-\mathrm{h}}$ & 29 & 3.97 & 0.57 & 0.89 & 34 & 3.90 & 0.44 & 0.86 & 18 & 3.4 & -2.1 & 0.89 & 20 & 0.30 & 0.17 & 0.86 \\
\hline$E C_{a-v}$ & 29 & 3.00 & 0.15 & 0.92 & 34 & 3.22 & 0.01 & 0.79 & -- & -- & -- & -- & 17 & 0.47 & -0.01 & 0.79 \\
\hline
\end{tabular}


1 Table 5. Effects of soil salinity $\left(E_{\text {e-h }}\right)$, gravimetric water content (WC) and saturation percentage (SP) on 2 EMI soil apparent $\mathrm{EC}_{a-h}$ in each Mediterranean irrigation district: number of sampling points $(\mathrm{N})$ and multiple 3 linear regression equations of standardized $\mathrm{EC}_{\mathrm{a}-\mathrm{h}}$ against standardized soil profile $E C_{e-h}$, WC and $\mathrm{SP}$. $4 \quad$ Numbers in parenthesis are probability $(P)$ values.

\begin{tabular}{|c|c|c|c|c|c|}
\hline & \multicolumn{5}{|c|}{$E C_{a-h}\left(d S m^{-1}\right)=a E_{e-h}\left(d S m^{-1}\right)+b W C(\%)+c S P(\%)$} \\
\hline & $\mathrm{N}$ & a & $\mathrm{b}$ & c & $\mathrm{R}^{2}$ adj. \\
\hline MOROCCO & 29 & $0.23(0.000)^{* * *}$ & $0.00(0.46)^{\mathrm{ns}}$ & $0.00(0.70)^{\mathrm{ns}}$ & $0.95(0.000)^{\star * *}$ \\
\hline SPAIN & 34 & $0.77(0.000)^{* * *}$ & $0.11(0.202)^{\mathrm{ns}}$ & $0.17(0.084)^{*}$ & $0.90(0.000)^{* \star *}$ \\
\hline TUNISIA & 18 & $1.01(0.000)^{\star * *}$ & $-0.12(0.399)^{\mathrm{ns}}$ & $0.03(0.779)^{\mathrm{ns}}$ & $0.88(0.000)^{* * *}$ \\
\hline TURKEY & 20 & $0.69(0.000)^{* * *}$ & - & $0.33(0.003)^{* *}$ & $0.86(0.000)^{* * *}$ \\
\hline
\end{tabular}


1 Table 6. Percent of total irrigated area (TIA) in each $\mathrm{EC}_{\mathrm{e}-\mathrm{h}}$ interval estimated from the $\mathrm{EC}_{\mathrm{e}-\mathrm{h}}$ maps obtained in

2 each Mediterranean irrigation district. The surface-weighted average $E C_{e-h}$ values $\left(E C_{e-h-s w a}\right)$ are also given.

\begin{tabular}{|c|c|c|c|c|c|c|c|}
\hline \multicolumn{2}{|c|}{ MOROCCO } & \multicolumn{2}{|l|}{ SPAIN } & \multicolumn{2}{|l|}{ TUNISIA } & \multicolumn{2}{|l|}{ TURKEY } \\
\hline $\begin{array}{c}\mathrm{EC}_{\mathrm{e}-\mathrm{h}} \text { interval } \\
\left(\mathrm{dS} \mathrm{m}^{-1}\right)\end{array}$ & $\begin{array}{l}\text { TIA } \\
(\%)\end{array}$ & $\begin{array}{c}\mathrm{EC}_{\mathrm{e}-\mathrm{h}} \text { interval } \\
\left(\mathrm{dS} \mathrm{m}^{-1}\right)\end{array}$ & $\begin{array}{l}\text { TIA } \\
(\%)\end{array}$ & $\begin{array}{c}\mathrm{EC}_{\mathrm{e}-\mathrm{h}} \text { interval } \\
\left(\mathrm{dS} \mathrm{m}^{-1}\right)\end{array}$ & $\begin{array}{l}\text { TIA } \\
(\%)\end{array}$ & 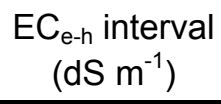 & $\begin{array}{l}\text { TIA } \\
(\%)\end{array}$ \\
\hline $0-1.7$ & 7.2 & $0-1.0$ & 54.3 & $0-2.5$ & 29.5 & $0.0-0.33$ & 14.1 \\
\hline $1.7-2.0$ & 16.5 & $1.0-2.5$ & 31.8 & $2.5-3.5$ & 34.4 & $0.33-0.40$ & 17.0 \\
\hline $2.0-2.3$ & 27.2 & $2.5-4.0$ & 9.2 & $3.5-4.5$ & 16.4 & $0.40-0.47$ & 18.0 \\
\hline 2.3-2.6 & 40.8 & $4.0-5.5$ & 3.0 & $4.5-5.5$ & 11.0 & $0.47-0.54$ & 37.0 \\
\hline$>2.6$ & 8.3 & $>5.5$ & 1.8 & $>5.5$ & 9.1 & $>0.54$ & 13.9 \\
\hline$E C_{\text {e-h-swa }}$ & 2.2 & $E C_{e-h-s w a}$ & 1.4 & $E C_{e-h-s w a}$ & 3.4 & $E_{\text {e-h-swa }}$ & 0.45 \\
\hline
\end{tabular}




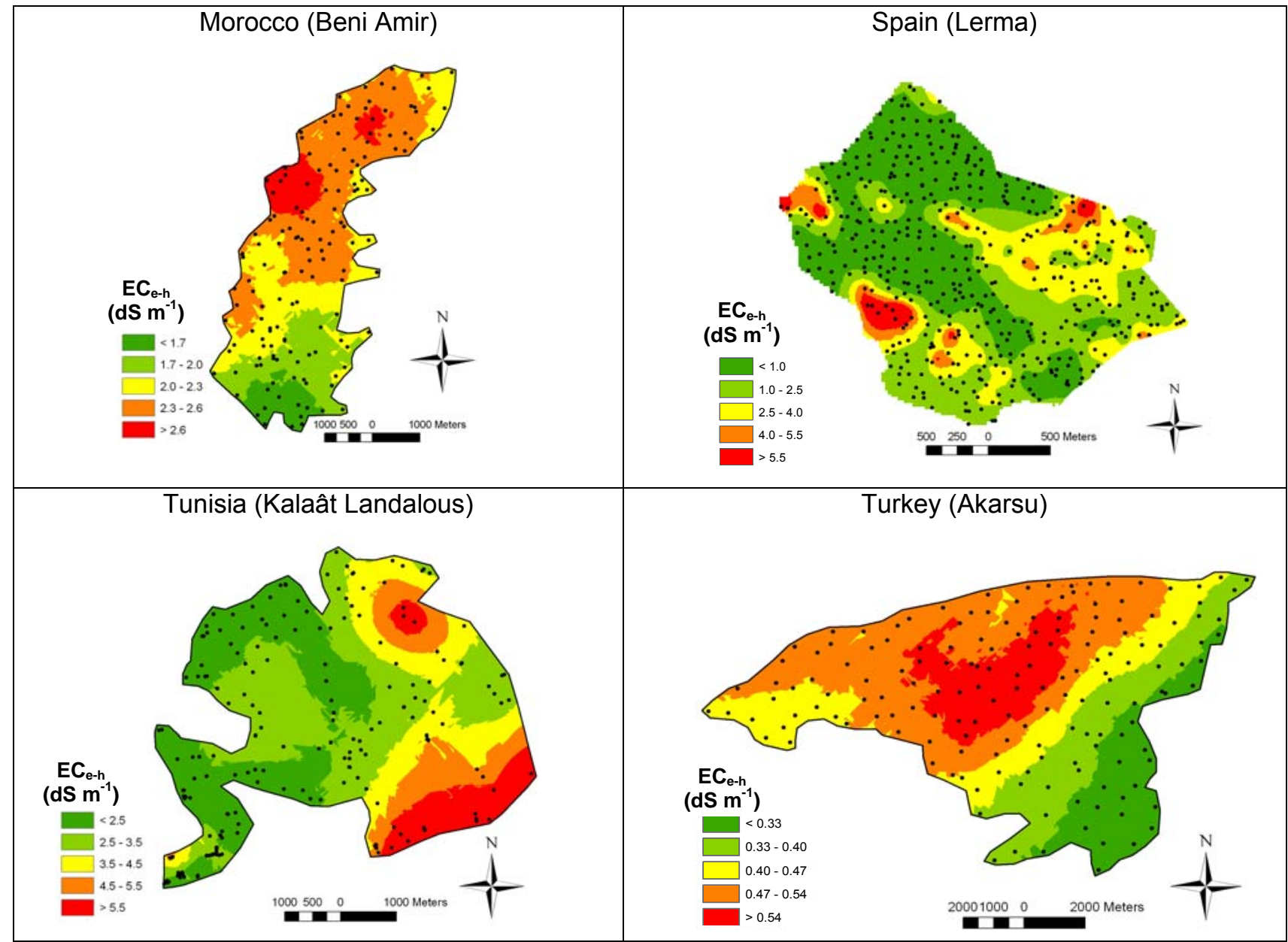

Fig. 1. Soil salinity $\left(E C_{e-h}\right)$ maps obtained in each Mediterranean irrigation district from the interpolated $E C_{a-h}$

4 values and the site-specific EMI sensor calibrations. Black points indicate the locations of the EMI survey. 